\title{
Combination of alum and extracted Moringa oleifera bioactive molecules powder for municipal wastewater treatment
}

\author{
Cheikhou KANE ${ }^{1 *}$, Aïcha BÂ ${ }^{1}$, Seïd Ali Malloum MAHAMAT², Nicolas AYESSOU ${ }^{1}$, \\ Maryam Khadim MBACKÉ ${ }^{1}$ and Codou Guèye MAR/DIOP ${ }^{1}$ \\ ${ }^{1}$ Laboratoire des Procécés Electrochimiques et Membranaires, Ecole Supérieure Polytechnique, \\ Université Cheikh Anta Diop, B.P : 5085, Dakar-Fann, Senegal. \\ ${ }^{2}$ Faculté des Sciences et Techniques de l'Université de Doba, Tchad. \\ "Corresponding author; E-mail: cheikhoukane.esp@gmail.com
}

\begin{abstract}
Most of wastewater treatment stations use aluminum sulfate $\left(\mathrm{Al}_{2}\left(\mathrm{SO}_{4}\right)_{3}, 18 \mathrm{H}_{2} \mathrm{O}\right)$ and ferric sulfate $\left(\mathrm{Fe}_{2}\left(\mathrm{SO}_{4}\right)_{3}\right)$ despite their relatively high cost. High turbidity of wastewater constitutes also a limit for a good treatment and increases the cost of the treatment. Moringa oleifera (MO) seeds are well known to have the ability to reduce turbidity and Chemical Oxygen Demand (COD) of wastewater. Moreover, most of the studies focus on using seeds directly for that purpose increasing consequently organic matter content. One of the major objectives of this study is to proposes a contribution for municipal wastewater treatment using crude $M O$ extracted protein powder (MOEP) for the first time for industrial applications. $\mathrm{NaCl}$ extraction of $M O$ defatted seeds bioactive molecule is first performed with a yield of $34 \%$ and the protein precipitated with ammonium sulfate $60 \%(\mathrm{~m} / \mathrm{v})$ and dried for coagulation as classical protein precipitation. Parameters affecting the effectiveness of $M O$ bioactive protein in wastewater treatment permits to operate at ambient temperature and a range of $\mathrm{pH}$ from 6 to 9 . The proposed process uses alum and $M O$ bioactive protein molecules powder as coagulant and as additive for classical municipal wastewater treatment. Within a ratio of 50:50 (w/w), more than $90 \%$ of the turbidity and $75 \%$ of COD. The results obtained with kaolin suspensions showed that MOEP is more efficient for higher turbid wastewater.
\end{abstract}

(C) 2016 International Formulae Group. All rights reserved.

Keywords: Moringa oleifera, coagulant, aluminum sulfate, precipitation.

\section{INTRODUCTION}

New regulations governing the quality of the discharge water make it necessary for industrial and domestic wastewater to reuse or damp cleaner water in lot of countries such as Senegal.

Aluminum and ferric salts are the most commonly used coagulants in water treatment because of their high efficiency for the removal of colloids. Cost and environmental side effects of these compounds have increased interest in the use of organic coagulants derived from plant material
(Chun-Yang, 2010; Fatombi et al., 2013) such as Moringa oleifera (MO) seeds (Jahn, 1988; Ghebremichael et al., 2005). However, most of the studies are focused on the use the seeds directly for turbidity removal (Bhatia et al., 2007), especially for drinking water (Ndabigengesere, Subba, 1998; Pritchard et al.; 2010; Natumanya, Oko-Okumu, 2015) Most of the studies concern the use of seeds directly for turbidity and COD removal, which increases consequently organic matter content (Poumaye et al., 2012; Tiea et al., 2015). 
Pritchard et al. (2010) compared the use of aluminum sulfate and powder obtained from MO seeds separately on purification of drinking water and showed that MO removed $84 \%$ turbidity and $88 \%$ E. coli, whereas alum removed greater than $99 \%$ turbidity and E. coli. Few studies focus on using a combination of $\mathrm{MO}$ and other coagulants such as arabic gum (Alang et al., 2011).

De Paula et al. (2014), by using a ratio of 20:80 (w/w) of MO seed powder and aluminum sulfate for concrete plant wastewater treatment for initial turbidity of about $120 \mathrm{NTU}$ and $\mathrm{pH} 12.5$, $90 \%$ of the turbidity was removed. The amount of aluminum sulfate was calculated in order to have a final $\mathrm{pH}$ ranging from 6 to 9 for water discharge or reuse in washing vehicles for example.

Bhuptawat and Folkard (2007), with aqueous extraction of the bioactive component of Moringa oleifera, treated a wastewater with initial turbidity of $13.5 \mathrm{NTU}$ and $150 \mathrm{mg} / \mathrm{L}$ of COD and $\mathrm{pH}=7.2$. The results indicated that by using the extracted bioactive component solution overall COD removal of $50 \%$ was achieved at both 50 and $100 \mathrm{mg} / \mathrm{L}$. They showed that when 50 and 100 $\mathrm{mg} / \mathrm{L}$ seed doses were applied in combination with $10 \mathrm{mg} / \mathrm{L}$ of alum for, COD removal increased to 58 and $64 \%$, respectively and the majority of COD removal occurred during the filtration process.

Okuda et al. (1999) developed a method for the extraction of active coagulation component from Moringa oleifera seeds and compared it with the ordinary water extraction method. The use of 1 $\mathrm{mol} / \mathrm{L}$ solution of sodium chloride and other salts were performed for extraction of the active coagulation component. The results showed better coagulation activity with dosages 7.4 times lower than that using ordinary water extraction method by distilled water for the removal of kaolinite turbidity.

Researches over the last decades focused essentially on testing MO on raw water with low turbidity by using its defatted oil-free seeds powder or by using aqueous extracted MO bioactive component solutions. These methods are not useful in larger scale such as in classical wastewater treatment stations. In order to address this question, the objective of this work is to study the extraction of the MO bioactive molecule as it has been done since now and then examine the possibility of separating it from the raw extraction solution and precipitate it as classical protein and dry it for the first time. This work concerns municipal wastewater treatment with relatively high turbidity by Moringa oleifera extracted and precipitated bioactive seeds component and dried as coagulant and as adjuvant with alum for municipal wastewater and in a synthetic kaolin solutions treatment characterization purpose.

\section{MATERIAL AND METHODS \\ Material}

All the chemicals used were of analytical grade. The $\mathrm{pH}$ and the conductivity of the solution were monitored using a $\mathrm{pH}$-meter 210-HANNA INSTRUMENTS and a conductimeter EC214HANNA INSTRUMENTS. Turbidity was monitored by using a turbid-meter HYDRCURE HE9 and centrifugation was performed by using a centrifuge UNIVERSAL 16A.

\section{Wastewater sample collection}

Wastewater sample were collected from the National Office of wastewater Treatment of Senegal, West Africa, at Dakar in the primary settling before the biological treatment and refrigerated at $4{ }^{\circ} \mathrm{C}$ before the analysis. The National Office of Wastewater Treatment is in charge of collecting and treating domestic wastewater and pluvial water of Dakar where there are more than 5 million people. Typical wastewater characteristics are given in Table 1.

\section{Coagulant used}

Moringa oleifera used as coagulant comes from Senegal. The matured dry pods of Moringa oleifera were collected directly on the trees and shelled and the seeds stored until used. The seeds must be matured and dry in order to make sure that there is bioactive coagulant in the seeds (Ndabigengesere, 1995).

\section{Preparation of Moringa oleifera}

Dry seeds are shelled and the kernel ground in an electric grinder to achieve first, oil extraction and dissolution of active ingredients in a second step. Shelled seeds and kernel grinded are presented in Figure 1.

\section{Oil extraction}

Fourty grams of Moringa oleifera grinded kernel were fed to a lab-scale Soxhlet extractor fitted with $500 \mathrm{~mL}$ round-bottom flask and a condenser. Extraction was performed for 4 hours with $500 \mathrm{~mL}$ of hexane as solvent. A total reflux during four hours permits to extract most of the oil. After this time, the hexane is condensed and separated with the oil. 
The extracted oil yield was expressed as percentage, which is defined as weight of oil extracted over weight of the sample taken.

\section{Coagulant bioactive component extraction and precipitation}

Ten grams of defatted seeds were mixed with $100 \mathrm{~mL}$ of sodium chloride (1M) using a magnetic stirrer for two hours. Then, the supernatant was separated by centrifugation $(6000$ rpm, $30 \mathrm{~min}$ ) and filtered in order to make sure there are no seeds residues.

The proteins precipitation was performed by using ammonium sulfate $60 \%(\mathrm{~m} / \mathrm{v})$ for the protein coagulation and precipitation (Andre et al., 2009; Jeso, 1968; Dixon, 1953). The proteins are separated with the supernatant by filtration and dried at room temperature to form fine powder (Figure 2).

\section{Coagulation with varying $\mathbf{p H}$}

In order not to increase the cost of wastewater treatment, it is important to determine the optimal $\mathrm{pH}$ with alum and Moringa oleifera extracted protein (MOEP). Initial wastewater $\mathrm{pH}$ was varied from 5 to 10 by using $\mathrm{NaOH}(1 \mathrm{M})$ and concentrated sulfuric acid (18M) solutions for $\mathrm{pH}$ adjustments.

\section{Coagulation with varying temperature}

The efficiencies of MOEP and alum coagulation against a variety of temperatures were tested. Laboratory refrigerators were used to bring samples to the required temperature overnight. A range of temperatures varying from 20 to $40{ }^{\circ} \mathrm{C}$ with the optimized doses of MOEP and alum concentrations were tested.

\section{Use of MOEP as additive with alum for} municipal wastewater

The optimum dose of alum was used as reference value and the percentages of MOEP were varied from 0 to $100 \%$ by measuring residual turbidity and residual COD in order to determine the maximum amount of MOEP which can be used as additive to reduce the cost of the classical treatment with alum.

Comparison of MOEP and alum as coagulant in kaolin suspensions

Experiments were carried out in samples of trouble water by adding kaolin particles in potable water. Kaolin was purchased in local market, grounded in fine particles. $10 \mathrm{~g}$ of the powder are then dissolved in a flask of $1 \mathrm{~L}$ and mixed during $24 \mathrm{~h}$ with a magnetic stirrer. After that, the suspension is settled during $24 \mathrm{~h}$ again in order to complete kaolin hydration (Olsen, 1987). This operation permits to settle non colloidal particles. The colloidal solution is then used for turbidity removal tests.

\section{RESULTS}

\section{Oil yield extraction}

Results obtained with Soxhlet oil extraction with hexane as solvent depended on time of extraction. Maximum oil yield extraction was $34.73 \%$ after 4 hours of extraction.

\section{Optimal contact time}

In order to determine the optimal contact time for turbidity removal, based on literature, a concentration of $200 \mathrm{mg} / \mathrm{L}$ of MOEP was chosen for the tests. Addition of the powder is followed by a rapid mixing of the solution (500 rpm) during 2 min, followed by a smaller mixing rate $(100 \mathrm{rpm})$ for $10 \mathrm{~min}$.

The results (Figure 3) indicated that settling time of about $2 \mathrm{~h}$ is need for the solution for $95 \%$ of turbidity removal.

Optimal coagulant concentrations of MOEP and alum

In order to determine the optimal coagulant concentration, reduction of turbidity versus coagulation concentration for both MOEP and alum are plotted as shown in Figure 4 for initial turbidity of 145 NTU.

\section{COD removal of MOEP and alum}

Figure 5 shows the influence of COD removal with MOEP and alum concentrations. The results indicate that as concentrations of both MOEP and alum increase, reduction in COD increases. The maximum COD reduction occurs at concentrations of $200 \mathrm{mg} / \mathrm{L}$ and $300 \mathrm{mg} / \mathrm{L}$ for MOEP and alum respectively as for the turbidity reduction. When the maximum are reached, increase in coagulant concentrations causes decrease in COD reduction.

\section{Optimal pH treatment}

The data show that maximum turbidity removal occurs at $\mathrm{pH}=6.2$ for alum and $\mathrm{pH}=9$ for MOEP. However, it can be seen that for MOEP, over $50 \%$ turbidity removal was achieved with $\mathrm{pH}$ ranging from 6 to 9 (Figure 6). 
Final conductivity of treated wastewater with MO coagulant concentration

The conductivity of treated municipal wastewater with MOEP does not increase the conductivity as shown in Figure 7. In contrast, the treatment with alum decreases the conductivity.

Turbidity removal depending on temperature

The optimal temperature for both alum and MOEP are comprised between 25 and $30{ }^{\circ} \mathrm{C}$ as shown in Figure 8.

Use of MOEP as additive with alum for municipal wastewater

The optimal dose of alum $(200 \mathrm{mg} / \mathrm{L})$ is used as reference and MOEP weight concentration adjusted to match that concentration. The results indicate that $50 \%$ of MOEP can be used as additive for turbidity removal. COD removal decreases when MOEP concentration is increased due to increase of organic matter (Figure 9).

Use of MOEP as coagulant in kaolin suspensions Three solutions of 195, 105 and 55 NTU were prepared by diluting kaolin initial solution. The solutions are stirred frequently in order to avoid settling of colloids and maintain initial concentration. Coagulation with MOEP is first performed and then with alum by varying coagulant concentrations. Results are presented in Figure 10.

Table 1: Indicative wastewater characteristics at $20^{\circ} \mathrm{C}$.

\begin{tabular}{lcccc}
\hline & pH & Conductivity $(\mathbf{m S} / \mathbf{c m})$ & Turbidity (NTU) & COD (mg/L) \\
\hline Wastewater sample & 8,2 & 4,63 & 145 & 528 \\
\hline
\end{tabular}

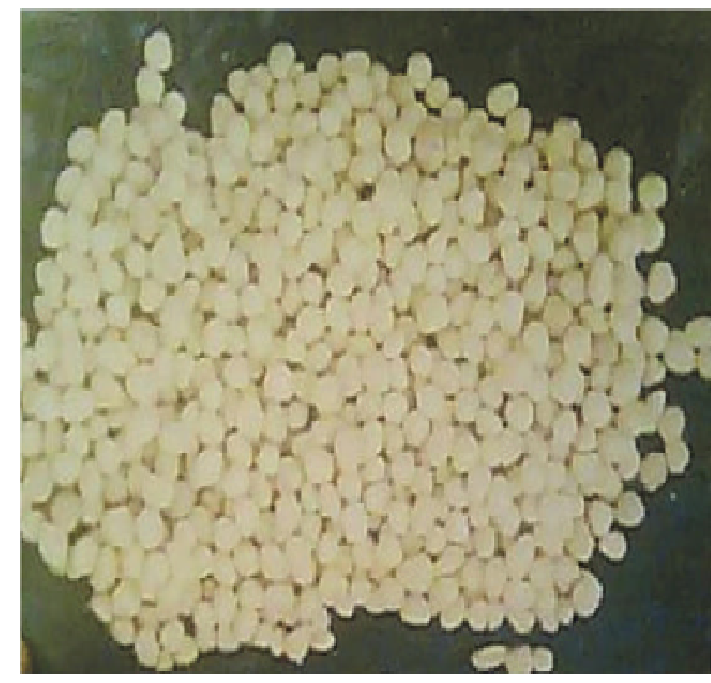

(a)

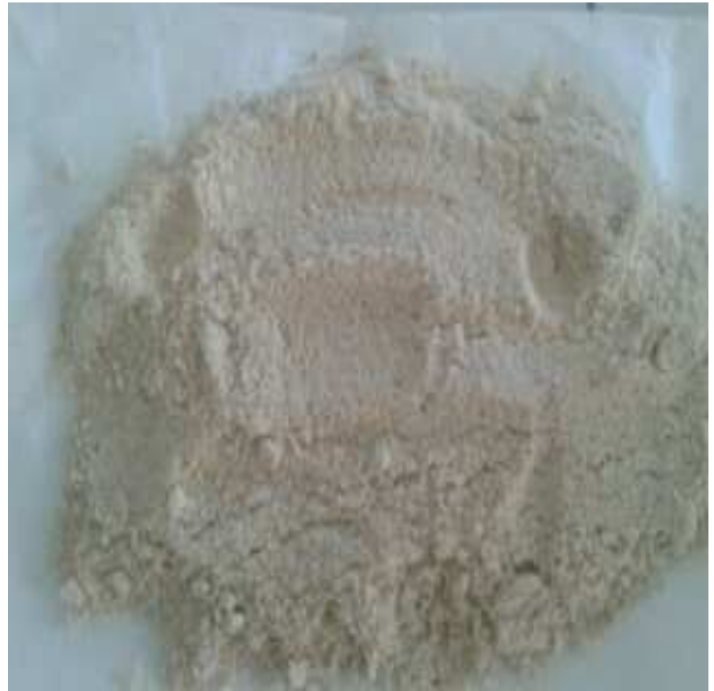

(b)

Figure 1 : Moringa oleifera shelled seeds (a) and ground kernel (b). 


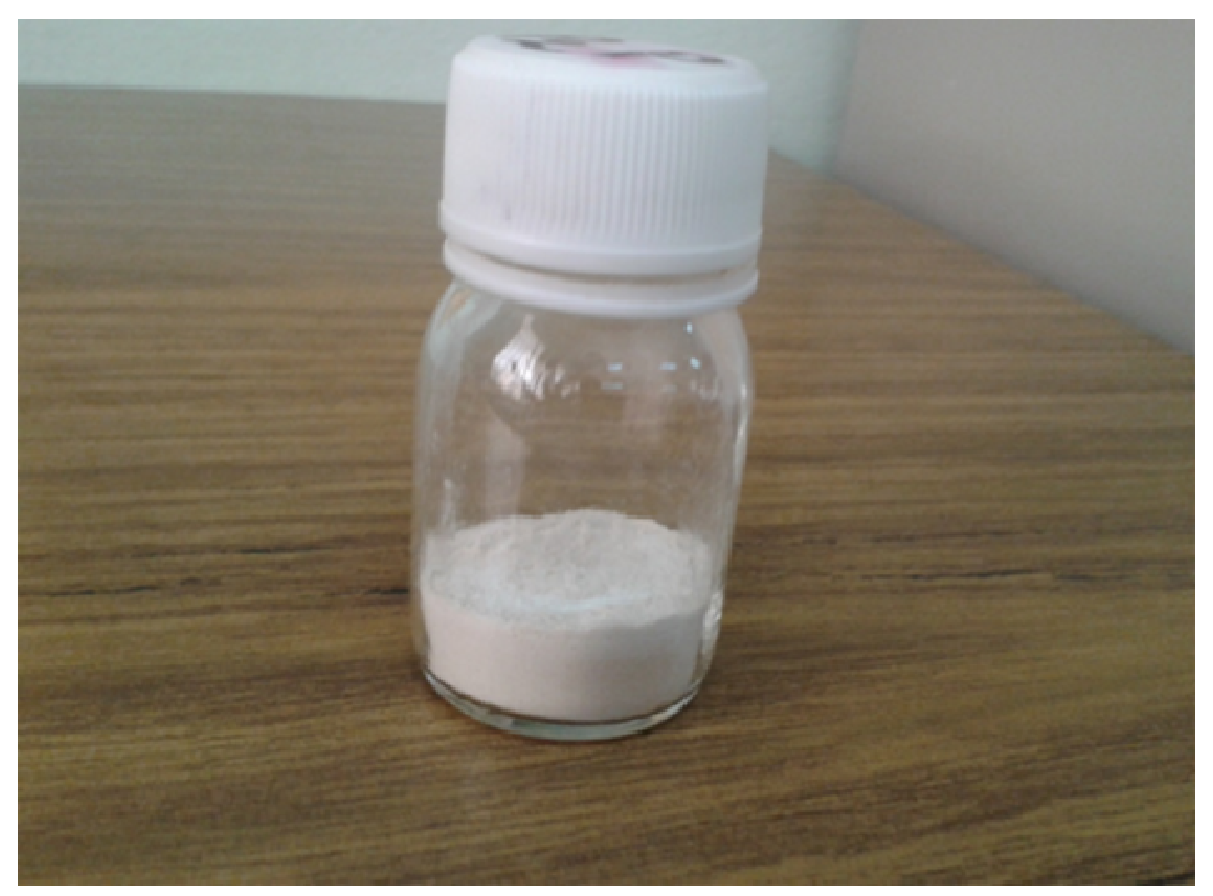

Figure 2: Moringa oleifera coagulant protein powder.

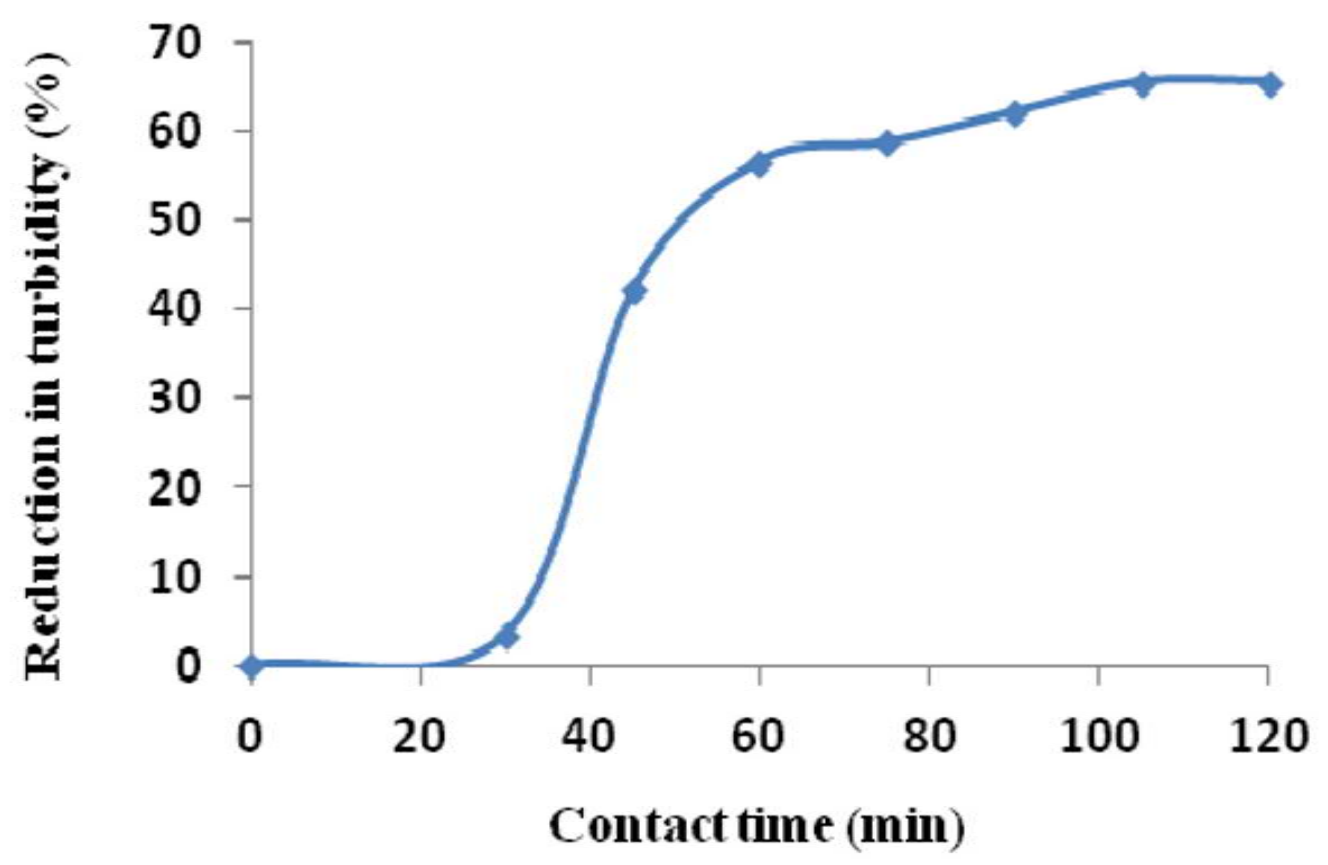

Figure 3: Turbidity removal depending on contact time. 


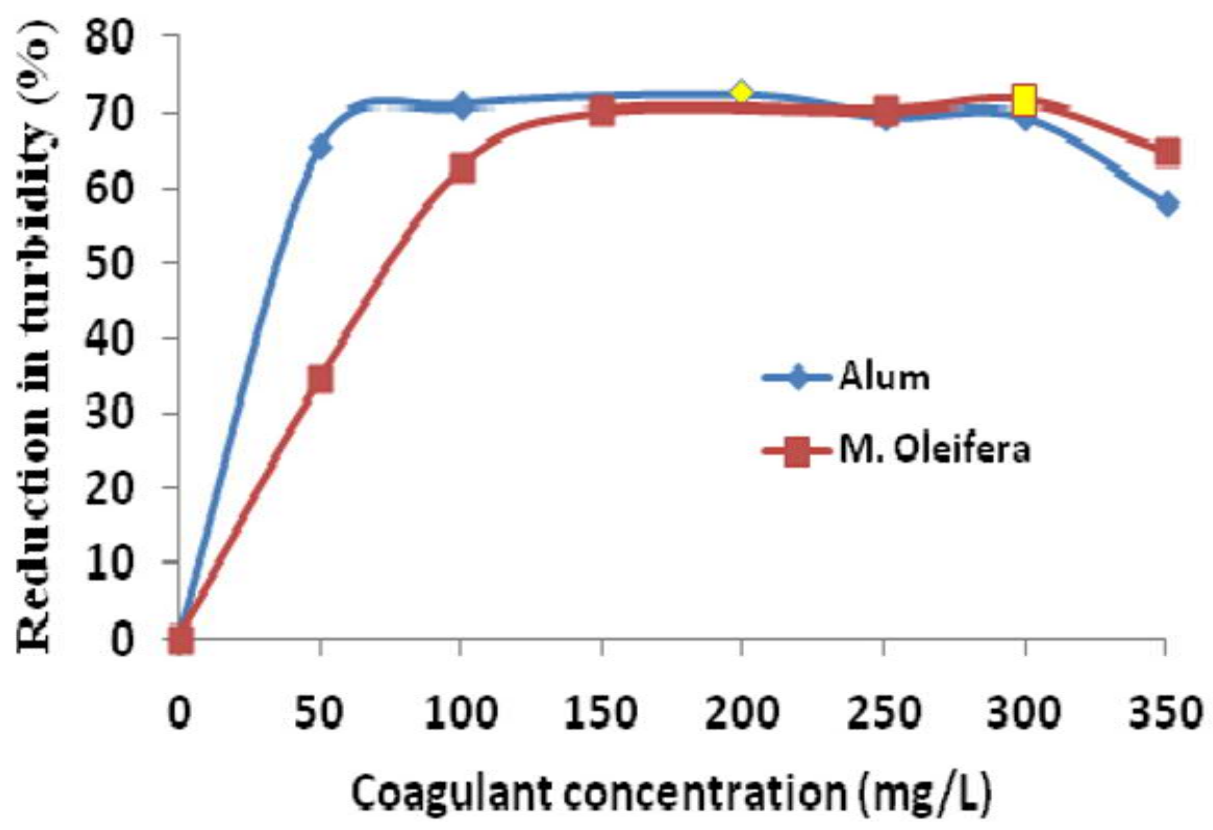

Figure 4: Turbidity removal depending on alum and MOEP concentration.

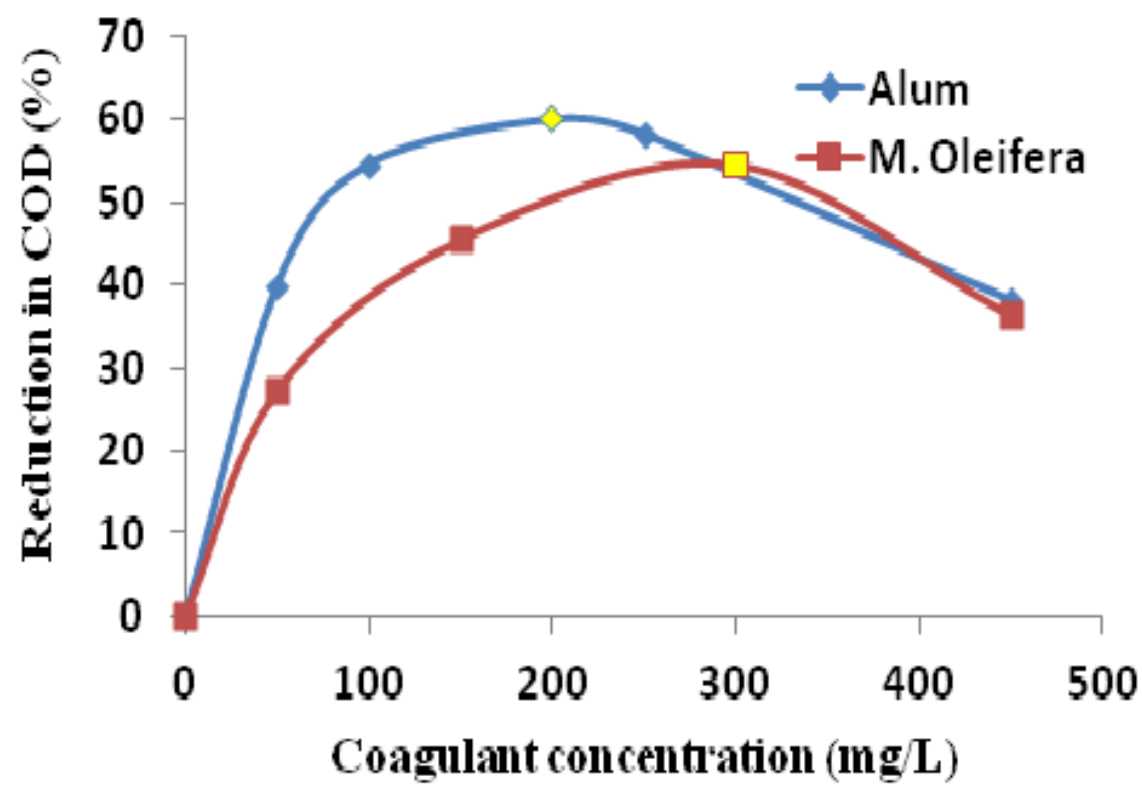

Figure 5: Reduction in COD depending coagulant concentration for alum and MOEP. 


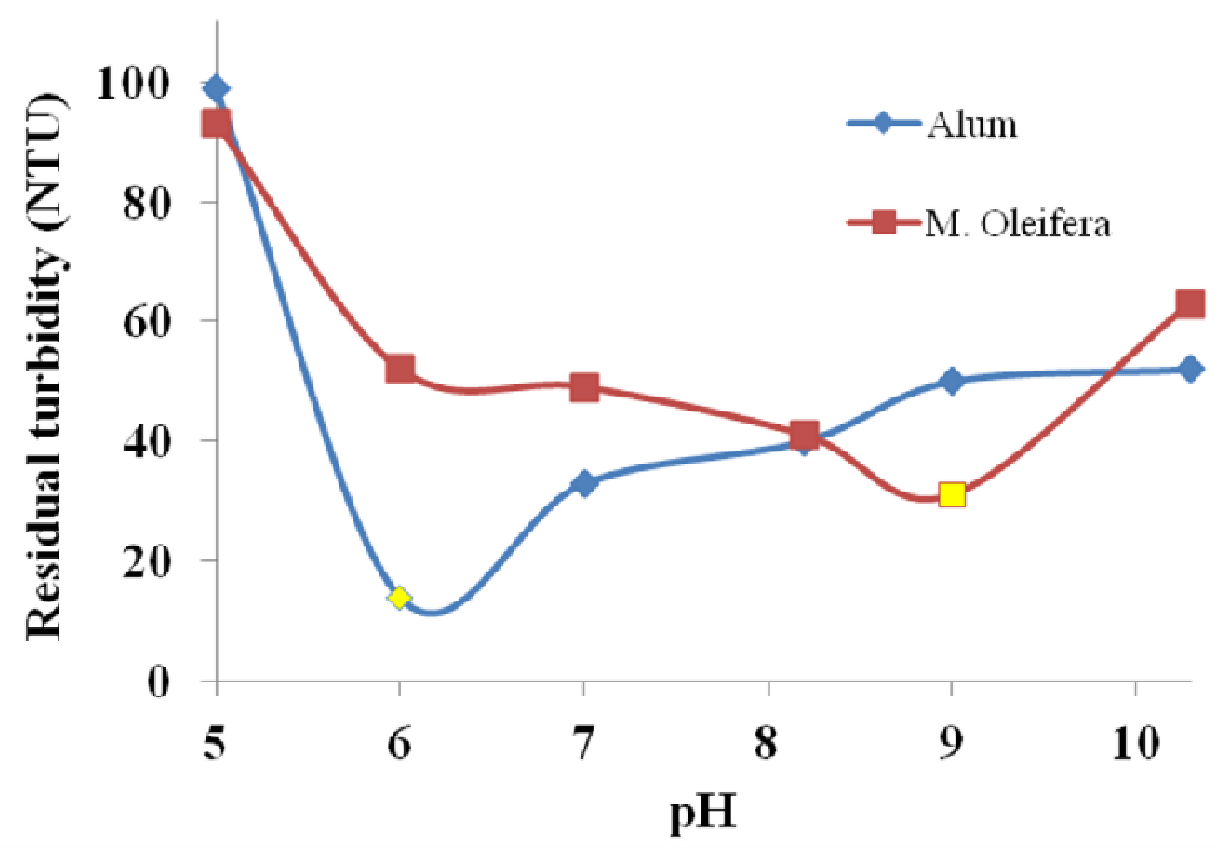

Figure 6 : Turbidity variation with $\mathrm{pH}$.

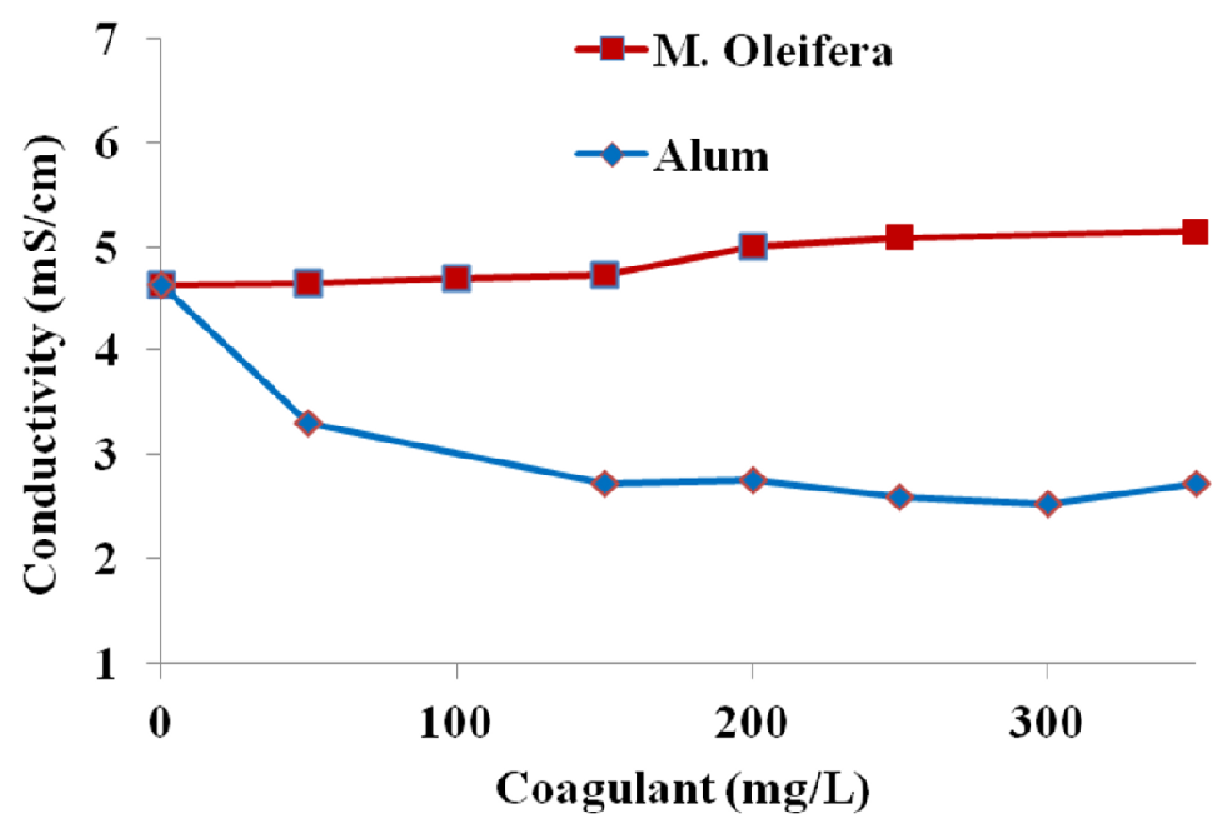

Figure 7: Residual conductivity depending on coagulant concentrations. 


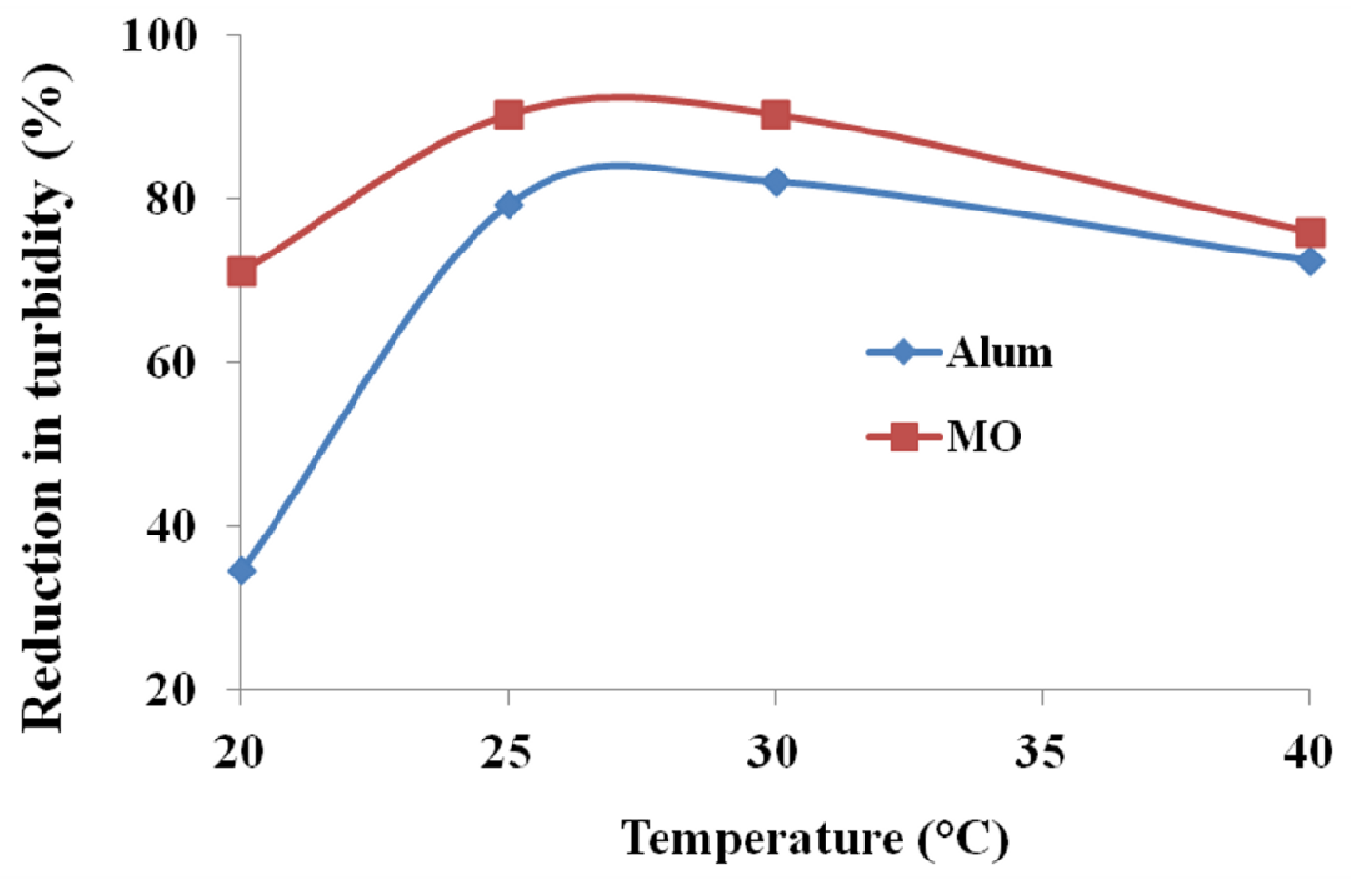

Figure 8: Optimal temperature for turbidity removal.

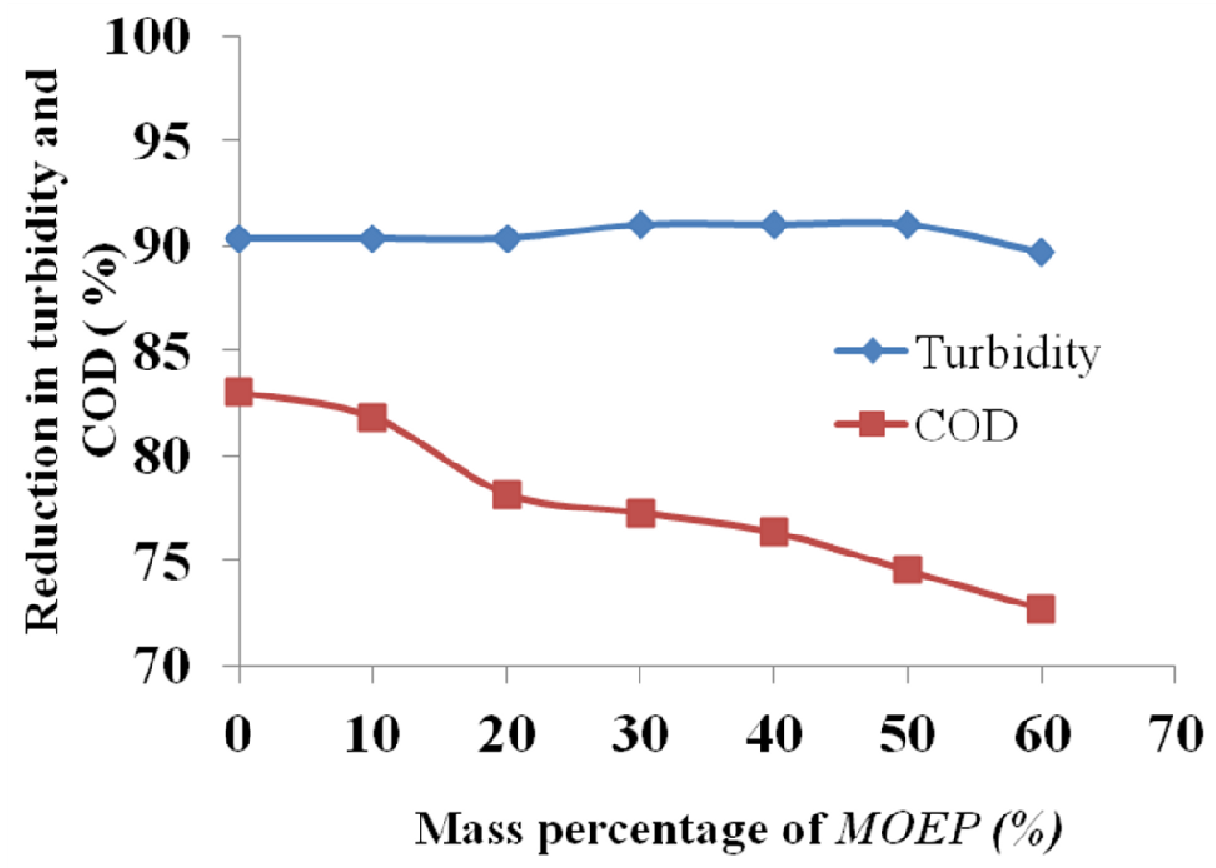

Figure 9: Turbidity and COD removal depending in mass percentage of MOEP as additive. 


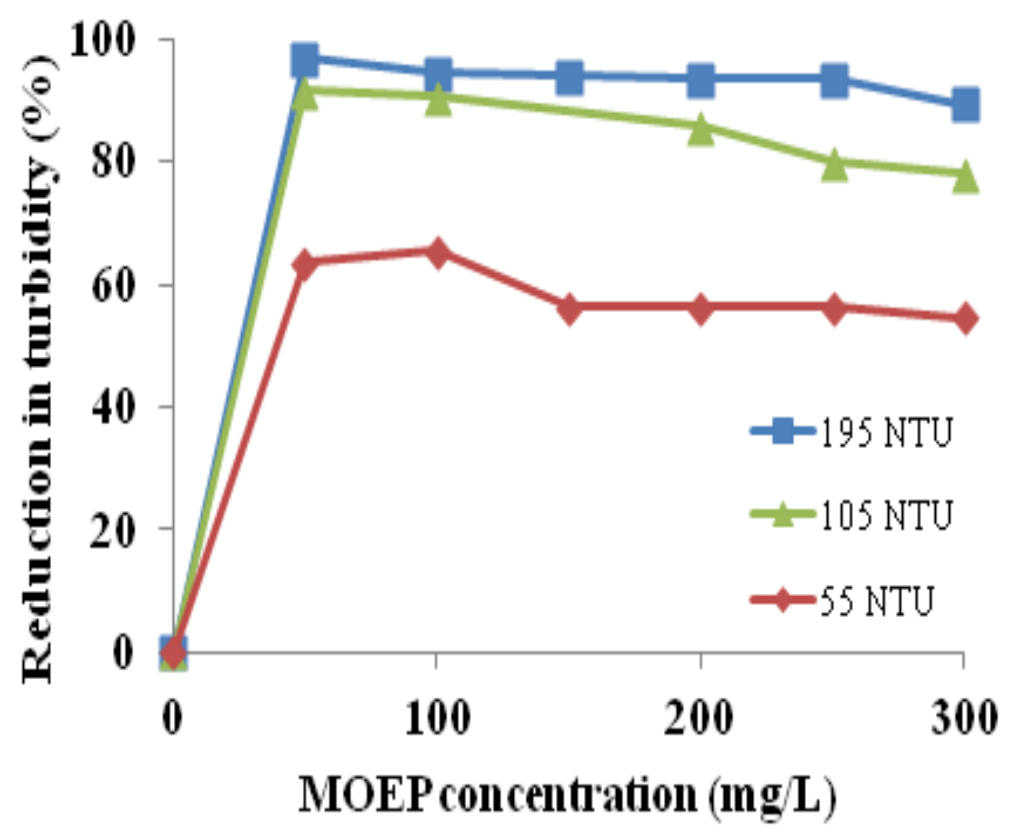

(a)

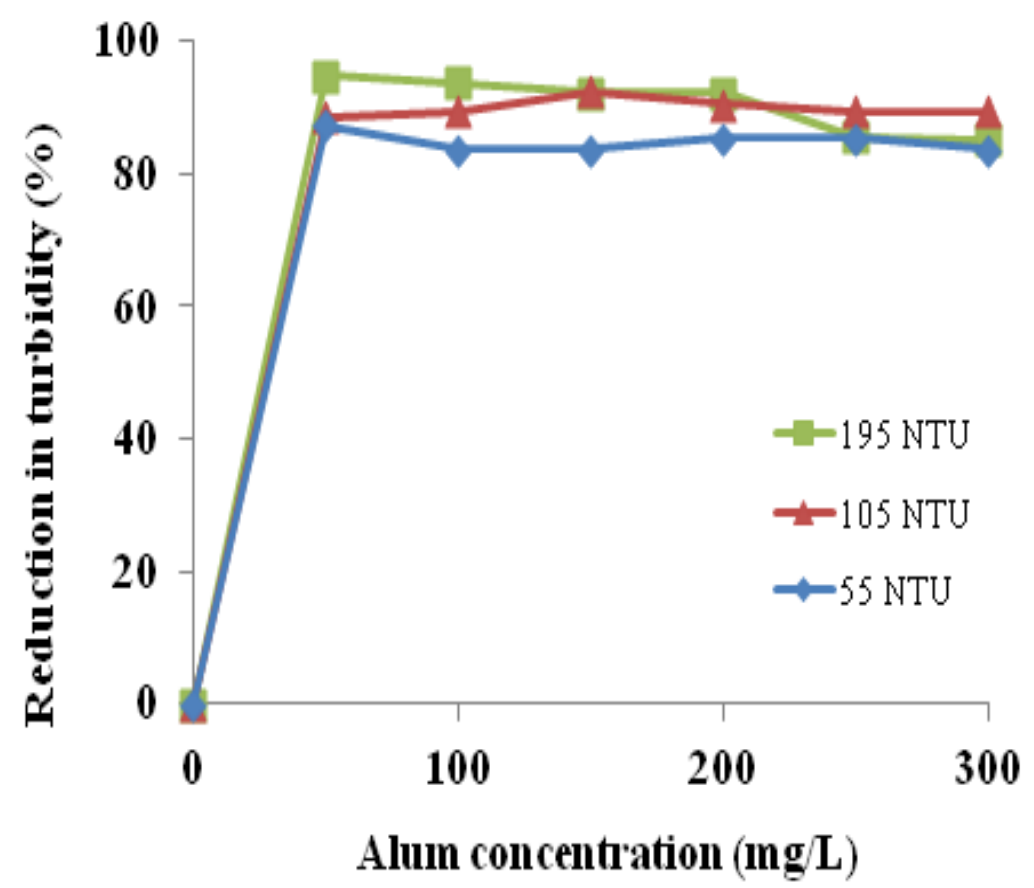

(b)

Figure 10 : Reduction in turbidity by using MOEP (a) and alum (b) for kaolin initial turbidity of 195NTU, $105 \mathrm{NTU}$ and 55NTU. 


\section{DISCUSSION}

The results of the oil extraction are in accordance with literature. According to the previous studies Moringa oleifera seeds have 30$35 \%(\mathrm{w} / \mathrm{w})$ of oil content (Premi and Sharma, 2013).

The two graphs in Figure 4 for turbidity removal show a similar trend. When the coagulant concentration is increased, reduction of turbidity increases and at about $\quad 50 \mathrm{mg} / \mathrm{L}$ of alum, the maximum turbidity reduction is reached while for MOEP, the maximum reduction in turbidity is reached for a concentration of $150 \mathrm{mg} / \mathrm{L}$.

When the coagulant concentration is increased at the maximum reduction in turbidity (71\%), there is no influence until the concentration equals $200 \mathrm{mg} / \mathrm{L}$ and $300 \mathrm{mg} / \mathrm{L}$ for alum and MOEP respectively. At these concentrations, reduction in turbidity decreases.

In general, for COD removal, when the coagulant concentration is increased in order to reduce the turbidity, organic matters negatively charged are also removed by a sweep coagulation mechanism (Packham, 1965; Fedala, 2015). However, when all the charges are neutralized, increase of coagulant concentrations may change the charge of the colloids; releasing again adsorbed organic matter, which reduces COD reduction. The same trend is observed for both alum and MOEP.

Moreover, the results for $\mathrm{pH}$ optimization for MOEP are similar to those obtained with MO grinded raw seeds coagulant for drinking water treatment (MPr10).

The temperature influences on turbidity removal show that in developing countries such as Senegal, theses temperatures are average ambient temperature. At relatively low temperature $(<25$ ${ }^{\circ} \mathrm{C}$ ), reduction in turbidity decreases due to increase in viscosity which decreases the settling time. This phenomenon increase generation of micro-flocks. The increase decrease in turbidity removal when the temperature is higher than $40{ }^{\circ} \mathrm{C}$ may be due to MOEP degradation. These results are similar to those obtained with the crude seeds in the literature (Ndabigengesere and Narasiah, 1996). The same trend is observed with alum. The phenomena can be explained with the reduction of viscosity and density.

The Use of MOEP as coagulant in kaolin suspensions show that these results are similar to those for natural water (Jahn and Dirar, 1979) treated with raw Moringa oleifera seeds. However, treated wastewater with alum for smaller or higher turbid solutions has shown no significant differences.

Results obtained with MOEP show that using Moringa oleifera as coagulant for turbidity removal is more efficient for relatively higher turbid wastewater (>100NTU).

\section{Conclusion}

The present study clearly shows that classical protein precipitation can be performed for Moringa oleifera protein precipitation. Optimum operating parameters such as $\mathrm{pH}$ and temperature for municipal wastewater treatment have been determined in the present study by using Moringa oleifera extracted protein with ammonium sulfate $60 \%(\mathrm{~m} / \mathrm{v})$. The results have shown almost the same effect than alum for turbidity removal, especially for higher turbid water. In order to reduce the cost of wastewater treatment, Moringa oleifera extracted protein can be used as additive with alum with a maximum mass concentration of $50 \%$. It seems that the active bioactive molecule of Moringa oleifera is a protein. More studies are needed for industrial production of Moringa oleifera protein powder.

\section{COMPETING INTERESTS}

The authors declare that they have no competing interests.

\section{AUTHORS' CONTRIBUTIONS}

$\mathrm{CK}$ and NA designed and supervised the study. $\mathrm{AB}$ was the principal investigator; she conducted all the experiments in this study. SAMM and MKM contributed in conducting the experiments. CGM/D is the head of the Laboratory.

\section{ACKNOWLEDGMENTS}

The authors would like to thank Ecole Supérieure Polytechnique de Dakar for its Technical assistance.

\section{REFERENCES}

Alang M, Barminas J, Ba A, Usaku RA. 2011. Comparative studies on the flocculation efficiencies of Moringa oleifera (MO), polyacrylamide-grafted gum arabic (GA-g- 
PAAM) and blended products of $\mathrm{MO}$ and PA-g-PAAM. Int. J. Biol. Chem. Sci, 5: 2140-2154. DOI

http://dx.doi.org/10.4314/ijbcs.v5i5.34

Andre F, Santos LA, Luz AC, Argolo JA, Teixeira PM, Paiva G. 2009. Isolation of a seed coagulant Moringa oleifera lectin. Process Biochem., 44: 504-508. DOI:10.1016/j.procbio.2009.01.002

Bhatia S, Othman Z, Ahmad AL. 2007. Coagulation-flocculation process for POME treatment using Moringa oleifera seeds extract: Optimization studies. Chem. Eng. Journal, 133 : 205-212. DOI: 10.1016/j.cej.2007.01.034

Bhuptawat HG, Folkard SC. 2007. Innovative physico-chemical treatment of wastewater incorporating Moringa oleifera seed coagulant. Journal of Hazardous Materials, 142 : 477-482. DOI: $10.1016 / j$. jhazmat.2006.08.044

Chun-Yang Y.2010. Emerging usage of plantbased coagulants for water and wastewater treatment. Process Biochem., 45: 14371444. DOI:10.1016/j.procbio.2010.05.030

De Paula HM, De Olivera Ilha MS, Andrade LS. 2014. Concrete plant wastewater treatment process by coagulation combining aluminum sulfate and Moringa oleifera powder. J. Cleaner Prod., 76: 125-130. DOI: $10.1016 /$ j.jclepro.2014.04.031

Dixon M. 1953. A Nomogram for Ammonium Sulphate Solutions. Biochem. J., 54: 457458.

Fatombi J, Avocanh G, Topanou N, Aminou TA. 2013. Elimination du fer et du manganèse d'une eau de surface par les graines de Moringa oleifera. Int. J. Biol. Chem. Sci., 7(3): 1379-1391. DOI http://dx.doi.org/10.4314/ijbcs.v7i3.43

Fedala NH. 2015. Physical parameters affecting coagulation of turbid water with Opuntia. Ecological Engineering, 77: 33-36. DOI:10.1016/j.ecoleng.2015.01.007

Ghebremichael KA, Gunaratnab K, Henrikssonc H, Brumerc H, Dalhammar G. 2005. A simple purification and activity assay of the coagulant protein from Moringa oleifera seed. Water Research, 39: 2338-2344. DOI:10.1016/j.watres.2005.04.012
Jahn SA, Dirar H. 1979. Study on natural water coagulants in Sudan, with special reference to Moringa oleifera seeds. Water SA, 5: 9097.

Jahn SA .1988. Using Moringa seeds as coagulants in developing countries. Journal American Water Works Association, 80(6): 43-50.

Jeso FD. 1968. Ammonium Sulfate Concentration Conversion Nomograph for $0{ }^{\circ} \mathrm{C}$. The Journal of Biological Chemistry, 243(8): 2022-2023.

Natumanya R, Oko-Okumu J. 2015. Evaluating coagulant activity of locally available Syzygium cumini, Artocarpus heterophyllus and Moringa oleifera for treatment of community drinking water, Uganda. Int. J. Biol. Chem. Sci., 9(6): 2535-2554.

Ndabigengesere AK, Narasiah S, Talbot BG. 1995. Active agents and mechanism of coagulation of turbid water using Moringa oleifera. Wat. Res., 29(2) : 703-710. DOI : http://dx.doi.org/10.4314/ijbcs.v9i6.3

Ndabigengesere A, Narasiah KS. 1996. Influence of operating parameters on turbidity removal by coagulation with Moringa oleifera seeds. Environ. Technology, 17(10): 1103-1112. DOI: $10.1080 / 09593331708616479$

Ndabigengesere A, Subba K. 1998. Quality of water treated by coagulation using Moringa oleifera seeds. Water Ressources, 32(3): 781-791. DOI: 10.1016/S00431354(97)00295-9

Okuda T, Baes AU, Mnishijima WN, Okada M. 1999. Improvement of extraction method of coagulation active components from Moringa. Water. Ressources, 33(15): 33733378. DOI: 10.1016/S0043-1354(99)000469

Okuda T, Baes A, Nishijimam U, Okada M. 2001. Isolation and characterization of coagulant extracted from Moringa oleifera seed by salt. Water Ressources, 35(2): 405-410. DOI: 10.1016/S0043-1354(00)00290-6

Olsen A. 1987. Low technology water purification by bentonite clay and Moringa oleifera seed flocculation as performed in Sudanese Villages: effects on Schistosoma. Water Research, 21(5): 517-522. DOI: 10.1016/0043-1354(86)90211-3 
Packham, FR. 1965. Some studies of the coagulation of dispersed clays with hydrolyzing Salts. Journal of Colloid Interface Science, 20(1): 81-92. DOI: 10.1016/0095-8522(65)90094-2

Poumaye N, Mabingui J, Lutgenb P, Bigan M. 2012. Contribution to the clarification of surface water from the Moringa oleifera: Case M'Poko River to Bangui, Central African Republic. Chem. Eng. Res. Design, 90: 2346-2352.

DOI:

10.1016/j.cherd.2012.05.017

Premi M, Sharma H. 2013. Oil extraction optimization and kinetics from Moringa oleifera (PKM 1) Seeds. Int. J. Agri. Food
Sci. Technol., 4: 371-378. DOI: 10.1007/s11694-016-9388-y

Pritchard M, Craven T, Mkandawire T, Edmondson AS, O'Neill JG. 2010. A study of the parameters affecting the effectiveness of Moringa oleifera in drinking water purification. Phys. Chem. Earth, 35: 791797. DOI: $10.1016 /$ j.pce.2010.07.020

Tiea J, Jian M, Li H, Zhang H, Zhang X. 2015. A comparison between Moringa oleifera seed presscake extract and polyaluminum chloride in the removal of direct black 19 from synthetic wastewater. Industrial Crops and Products, 74: 530-534. DOI: 10.1016/j.indcrop.2015.04.004 